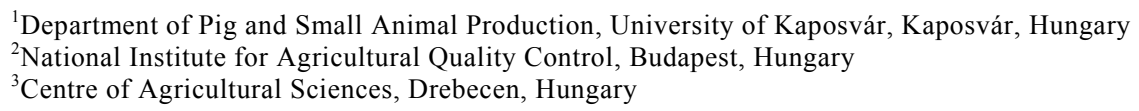

ZSÓFIA VÍGH ${ }^{1}$, PETRA GYOVAI ${ }^{1}$, LÁSZLÓ CSATÓ ${ }^{1}$, ÁRPÁD BOKOR ${ }^{1}$, JÁNOS FARKAS ${ }^{1}$, LÁSZLÓ RADNÓCZI ${ }^{2}$, ISTVÁN KOMLÓSI ${ }^{3}$ and ISTVÁN NAGY ${ }^{1}$

\title{
Effect of inbreeding on lean meat percentage and average daily gain in Hungarian Landrace pigs
}

\begin{abstract}
Pedigree and field test data - collected between 1994-2005 - were analyzed in a group of 132,548 Hungarian Landrace pigs. The analysed traits were average daily gain (ADG) and lean meat percentage (LMP). In the present study inbreeding coefficients, pedigree completeness (complete generation equivalents) and inbreeding depression for ADG and LMP were estimated. Increasing the number of generations that were considered in the pedigree the estimated inbreeding coefficients did not change after the $5^{\text {th }}$ generation, but pedigree completeness was continuously increased. The estimated inbreeding depression for ADG and LMP were different applying 40 different models but the magnitude of the differences was small. The model comparison showed that the models containing litter and year-month effects had the best fit (smallest mean squared error). Increasing the inbreeding coefficient by $10 \%$ decreased ADG by $4.01 \mathrm{~g}$ and practically did not affect LMP $(0.003 \%)$. It can be concluded that the estimated inbreeding depression was small and substantial depression can not be expected in the near future. However, the low level of inbreeding of the studied population can partly be explained by the short pedigrees. This suggests that Hungarian pig breeders may often import breeding animals or carry out herd replacements rather than applying continuous within group selection.
\end{abstract}

Keywords: pig, landrace inbreeding coefficients, inbreeding depression, daily gain, lean meat percentage

\section{Zusammenfassung}

Titel der Arbeit: Einfluss der Inzucht auf die tägliche Zunahme und den Muskelfleischanteil bei Schweinen der Ungarischen Landrasse

Es wurden die Abstammungs- und Feldtestdaten der täglichen Zunahme sowie des Muskelfleischanteils von 132.584 Landrassetieren aus den Jahren 1994-2005 ausgewertet. Ermittelt wurde der Inzuchtkoeffizient bei Berücksichtigung der dritten bis siebten Generation sowie die Inzuchtdepressionen bei den untersuchten Merkmalen. Nach der fünften Generation ergaben sich im Gegensatz zur dritten und vierten einbezogenen Generationen keine nennenswerten Veränderungen der Inzuchtkoeffizienten. Bei den 40 verglichenen Modellen fanden sich kaum Unterschiede. Im Vergleich der Modelle zeigte sich, dass die Genauigkeit derjenigen Modelle zunahm in denen auch die Wurf- und Jahr-Monat-Effekte eine Rolle spielten. Eine Zunahme des Inzuchtkoeffizienten um $10 \%$ war mit einer Verringerung der täglichen Zunahmeleistung von 4,01 g und keinem nennenswerten Effekt beim Muskelfleischanteil verbunden. Im Ergebnis ist festzustellen, dass die ermittelten Depressionen sehr gering sind und auch künftig kaum mit Auswirkungen der Inzucht zu rechnen ist. Verursacht wird diese Situation durch häufige Zuchttierimporte wodurch das Inzuchtniveau der ungarischen Landrassepopulationen relativ niedrig ist.

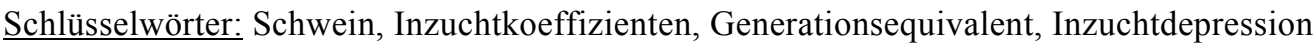

\section{Introduction}

One of the disadvantageous effects of inbreeding is the reduction of the mean phenotypic value of a trait known as inbreeding depression. Numerous authors experienced inbreeding depression in different domestic (MIGLIOR et al., 1995; WIENER et al., 1992; HORN and MELEG, 2000; CURIK et al., 2003; BRADE, 1991; FREYER et al., 2005; 
KOLK GEN SUNDAG et al., 2006; TRIEBLER et al., 1980; WOCAC, 2003; ZELLER and PIRCHNER, 1993) and experimental (ISSA and SEELAND, 2001) populations. Inbreeding depression is mainly apparent in traits that are closely related to fitness (FALCONER and MACKAY, 1996; PIRCHNER, 2004), but the reduction is not confined to reproductive traits. The negative effects of inbreeding are magnified by the fact that they often affect several traits (such as litter size at birth, mortality during the suckling period, litter weight at 21 days of age) simultaneously and are operating through litters and through dams. The inbreeding depression in domesticated species is mainly important because it affects production efficiency. The National Institute for Agricultural Quality Control collects pedigree and field test data of the Hungarian pig populations for many years which are being evaluated routinely with linear (animal) models. However, extensive study on the pedigree based inbreeding level and the inbreeding depression for the collected traits has not yet been accomplished. The objective of this study was therefore to estimate the level of inbreeding of the Hungarian Landrace population and comparison of different models for estimation of inbreeding depression for the collected field test traits, namely average daily gain and lean meat percentage.

\section{Materials and methods}

\section{Data recording}

The analysis was conducted on the data collected by the National Institute for Agricultural Quality Control of Hungary between 1994 and 2005, in course of field test. Data of 132,548 Hungarian Landrace pigs reared in 49,717 litters were analyzed, originated from 97 herds. In the field test ultrasonic measurements were taken from boars and gilts between 80 and $110 \mathrm{~kg}$. The measured traits were the fat depth between the $3^{\text {rd }}$ and $4^{\text {th }}$ lumbar vertebrae $(8 \mathrm{~cm}$ laterally from the spinal chord $)$, fat depth between the $3^{\text {rd }}$ and $4^{\text {th }}$ ribs $(6 \mathrm{~cm}$ laterally from the spinal chord $)$ and the loin muscle depth between the $3^{\text {rd }}$ and $4^{\text {th }}$ ribs $(6 \mathrm{~cm}$ laterally from the spinal chord). Using these measurements lean meat percentage values (LMP) were calculated. Age and body weight (with an accuracy of $1 \mathrm{~kg}$ ) of the animals were recorded at the same time from which their average daily gain (ADG) was also calculated. Gilts were kept in groups up to 25 pigs while boars were raised in smaller groups up to 15 using ad libitum feeding regime (OMMI, 2004). Basic statistics of the field test data are presented in Table 1.

Table 1

Mean and standard deviation of the average daily gain and lean mean percentage and their composite traits (Mittelwert und Standardabweichung von täglicher Zunahme und Muskelfleischanteil)

\begin{tabular}{|c|c|c|c|}
\hline Traits & No. of records & Mean & Standard deviation \\
\hline Average daily gain (g/ day) ${ }^{\mathrm{a}}$ & 132,548 & 532.3 & 62.2 \\
\hline Lean meat percentage $(\%)^{b}$ & 132,548 & 57.6 & 2.1 \\
\hline Age (day) & 132,548 & 182.7 & 24.5 \\
\hline Body weight (kg) & 132,548 & 96.2 & 9.3 \\
\hline
\end{tabular}

$\mathrm{a}=$ (body weight $[\mathrm{kg}]$ at the end of the field test/age at the end of the field test [day]) $1000 ; \mathrm{b}=56.333381-0.122854 \cdot$ fatdepth1$0.786312 \cdot$ fat depth $2+0.006160 \cdot$ fat depth $2 \cdot$ fat depth $2+0.237677 \cdot$ loin muscle depth (using SONOMARK 100 on live pigs)

\section{Pedigree analysis}

The total number of animals in the pedigree was 144,196 , the number of non-base animals was 138,802. Data analysis was started with pedigree analysis using the PEDUTIL, NGEN and VANRAD software packages. The first step was accommodating 
the pedigree data according to the animals with field test records using the PEDUTIL program. Pedigree completeness for every individual was assessed by formula of BOICHARD et al. (1997):

$$
\frac{1}{N} \sum_{j=1}^{N} \sum_{i=1}^{n_{j}} \frac{1}{2^{g_{i j}}}
$$

where $N=$ the number of animals in the reference population, $n_{j}=$ the total number of ancestors of animal $j$ and $g_{i j}=$ the number of generations between $j$ and its ancestor $i$.

Pedigree completeness was assessed by tracing back the pedigree for three, four, five, six and seven generations $\left(p c_{3}-p c_{7}\right)$. Inbreeding coefficient $(F)$ (WRIGHT, 1922) was calculated of each individual using VANRAD program.

Inbreeding coefficient was assessed by tracking back the pedigree of three, four, five, six and seven generations. $\left(F_{3}-F_{7}\right)$. The applied programmes are all part of the PEDIG software package (BOICHARD, 2002). After these calculations the results from pedigree analysis were joined with the field test records (PROC MERGE, SAS Institute Inc., 2004).

\section{Genetic parameters estimation}

Genetic parameters and breeding values were estimated using the PEST (GROENEVELD, 1990) and VCE-5 (KOVAC and GROENEVELD, 2003) software packages based on the BLUP and REML methods. 40 bivariate animal models were used for both traits. The model variations are presented in Table 2.

Table 2

Model variations applied for average daily gain and lean meat percentage (Modellvariationen, angewendet auf die tägliche Zunahme und den Muskelfleischanteil)

\begin{tabular}{|c|c|c|c|c|c|c|c|c|c|}
\hline Model & $\mathrm{F}_{\mathrm{i}}^{\mathrm{a}}$ & $\mathrm{pc}_{\mathrm{i}}^{\mathrm{b}}$ & $\begin{array}{l}\text { Year-month/ } \\
\text { month }\end{array}$ & Month & Sex & $\begin{array}{c}\text { Herd/ } \\
\text { herd-year }\end{array}$ & Herd-year & Animal & Litter \\
\hline $1-5$. & $x$ & - & $x$ & - & $x$ & $x$ & - & $x$ & - \\
\hline 6-10. & $\times$ & $x$ & $x$ & - & $x$ & $x$ & - & $x$ & - \\
\hline $11-15$. & $\times$ & - & $x$ & - & $x$ & $x$ & - & $x$ & $x$ \\
\hline $16-20$. & $x$ & $x$ & $x$ & - & $x$ & $x$ & - & $x$ & $\times$ \\
\hline $21-25$ & $\times$ & - & - & $x$ & $x$ & - & $x$ & $x$ & - \\
\hline $26-30$. & $x$ & $x$ & - & $x$ & $x$ & - & $x$ & $x$ & - \\
\hline $31-35$. & $\times$ & - & - & $x$ & $x$ & - & $x$ & $x$ & $\times$ \\
\hline $36-40$. & $x$ & $x$ & - & $x$ & $x$ & - & $x$ & $x$ & $\times$ \\
\hline
\end{tabular}

The basic linear model was the following:

$$
y=X b+Z a+W c+e
$$

where $y=$ vector of observations, $b=$ vector of fixed effects, $a=$ vector of random animal effects, $c=$ vector of random litter effects, $e=$ vector of random residual effects, $X, Z, W=$ incidence matrices relating records to fixed effects, random animal and random litter effects, respectively. Inbreeding coefficients $(F)$ and pedigree completeness $(p c)$ were defined as covariates, herd or herd-year, sex and year-month or month effects were defined as fixed effects, litter and animal effects were defined as random effects in the model. Inbreeding depression (the BLUE estimate of $F$ ) referring to the analyzed period was determined for ADG and LMP. The applied 40 models were compared according to their mean squared error (MSE) using the PREDICT option of the PEST software package. 


\section{Results and discussion}

The results of the pedigree analysis can be seen in Table 3 .

Table 3

Basic statistics of pedigree completeness and inbreeding coefficients (Übersicht der Abstammungsgenerationen und Inzuchtkoeffizienten)

\begin{tabular}{lccccc}
\hline Trait & No. of records/inbred animals & Minimum & Maximum & Mean & $\sigma$ \\
\hline $\mathrm{pc}_{3}$ & 132,548 & 0.5 & 3.0 & 1.64 & 0.72 \\
$\mathrm{pc}_{4}$ & 132,548 & 0.5 & 4.0 & 1.71 & 0.81 \\
$\mathrm{pc}_{5}$ & 132,548 & 0.5 & 4.75 & 1.72 & 0.84 \\
$\mathrm{pc}_{6}$ & 132,548 & 0.5 & 4.98 & 1.72 & 0.84 \\
$\mathrm{pc}_{7}$ & 132,548 & 0.5 & 5.01 & 1.72 & 0.84 \\
$\mathrm{~F}_{3}(\%)$ & 5,153 & 3.0 & 35 & 8.0 & 7.0 \\
$\mathrm{~F}_{4}(\%)$ & 8,555 & 1.0 & 35 & 6.0 & 6.0 \\
$\mathrm{~F}_{5}(\%)$ & 9,381 & 0.1 & 38 & 5.0 & 6.0 \\
$\mathrm{~F}_{6}(\%)$ & 9,513 & 0.1 & 38 & 5.0 & 6.0 \\
$\mathrm{~F}_{7}(\%)$ & 9,514 & 0.1 & 38 & 5.0 & 6.0 \\
\hline
\end{tabular}

Minimum maximum and mean values of inbreeding coefficients were calculated using values greater than zero.

When tracing more generations in the pedigree the estimated inbreeding coefficients did not change after the 5 generations, but pedigree completeness was continuously increased. The estimated inbreeding depressions for ADG and LMP showed small differences applying 40 different models (Figure 1 and Figure 2).

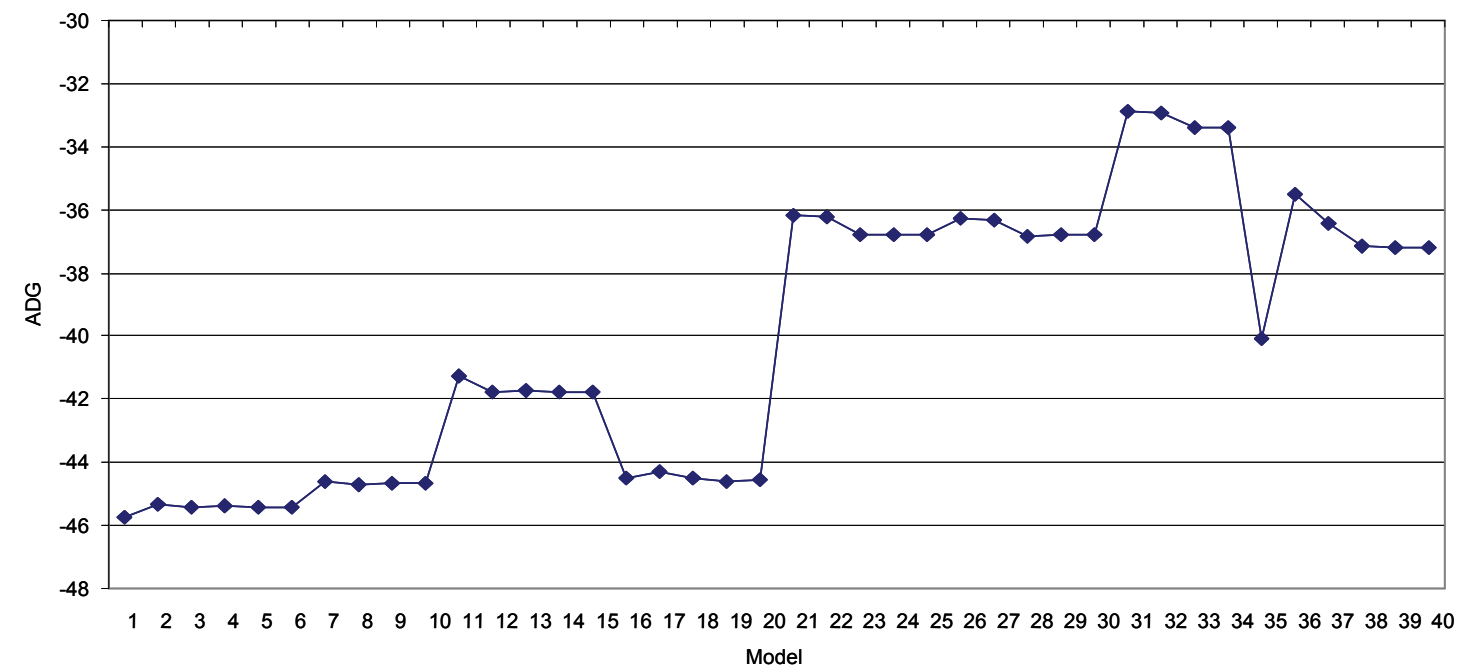

Fig. 1: The estimated inbreeding depressions for ADG (Geschätzte Inzuchtdepressionen für tägliche Zunahme)

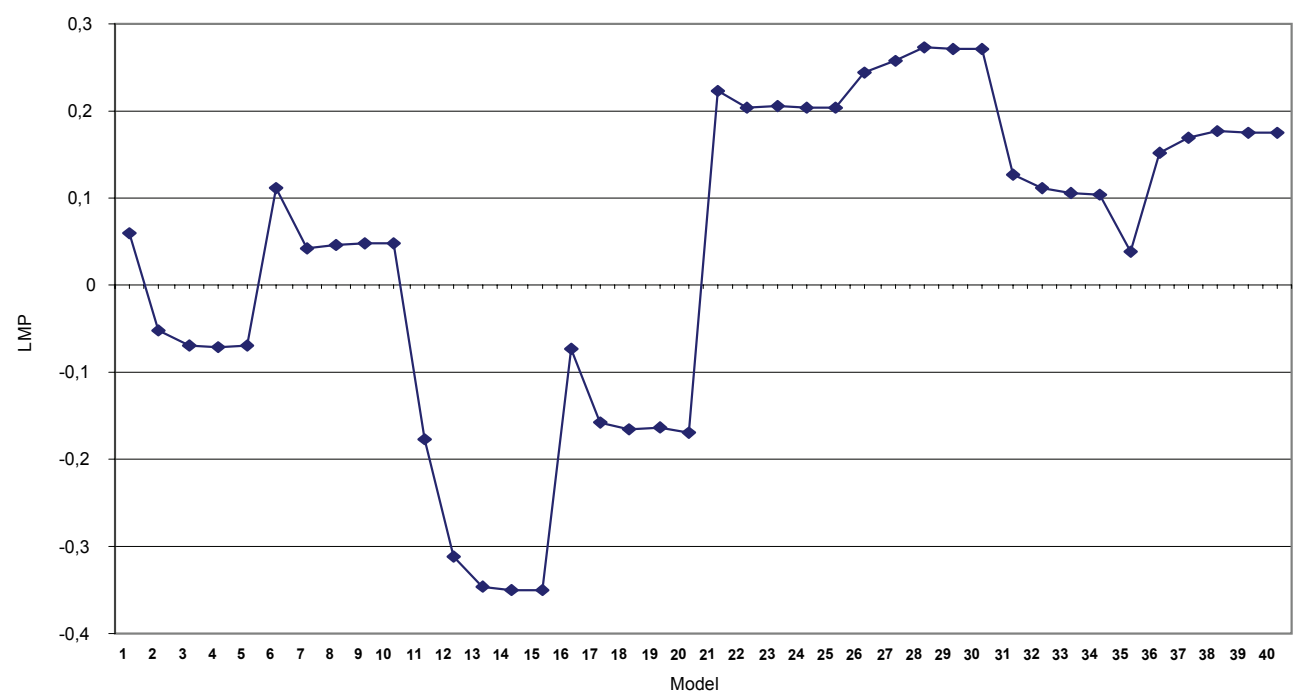

Fig. 2: The estimated inbreeding depression for LMP (geschätzte Inzuchtdepressionen für Muskelfleischanteil) 
Increasing the inbreeding coefficients by $10 \%$ decreased the ADG by $4.01 \mathrm{~g}$ (that corresponds to $0.73 \mathrm{~kg}$ decrease of body weight) and practically did not affect LMP $(0.003 \%)$.

Contrary to our results other authors observed substantial inbreeding depression in pigs for their body weight at 154 days of age. By increasing the inbreeding coefficients with $10 \%$ the reduction of the trait varied between 1.16-2.6 kg (BERESKIN et al., 1968; DICKERSON et al., 1954). In German Landrace tested in fattening performance test station (TRIEBLER et al., 1980) found a reduced body mass of $2.17 \mathrm{~kg}$ with $10 \%$ of increase of inbreeding coefficient. Furthermore animals with an inbreeding coefficient between 6.0 to $12.5 \%$ showed an extended test time of 6.5 days. BRANDT and MÖLLERS (1999) in Göttinger Minipig population found that a $10 \%$ increase of inbreeding of sows or litters both leads to a reduction on weight within the first 6 months of $0.25 \mathrm{~kg}$. According to CURIK et al. (2001) the inbreeding depression is determined by:

$$
-F \sum 2 p q d
$$

where $d$ depends on the degree of dominance, $p$ and $q=$ allele frequencies that affect the character. Thus the reason of the heterogeneity of inbreeding depressions found by different authors may be explained by the much higher inbreeding levels of the foreign pig populations. DICKERSON et al. (1954), BERESKIN et al. (1968) and BRANDT and MÖLLERS (1999) examined 4,521, 7,075 and 1,191 litters, where the average inbreeding coefficients were $0.24,0.16$ and 0.10 , respectively and the maximum level of inbreeding reached 0.7 . The mean inbreeding coefficient of the living population in the German Bentheimer pig race amounts to $8.01 \%$ (KOLK GEN SUNDAG et al., 2006). However, only 4 boars have been integrated during the last 25 years from outside into this closed population. For LMP inbreeding had no effect on the trait, the Hungarian Landrace population possibly did not exhibit directional dominance.

The comparison of the 40 animal model's fit can be seen in Figure 3 and Figure 4.

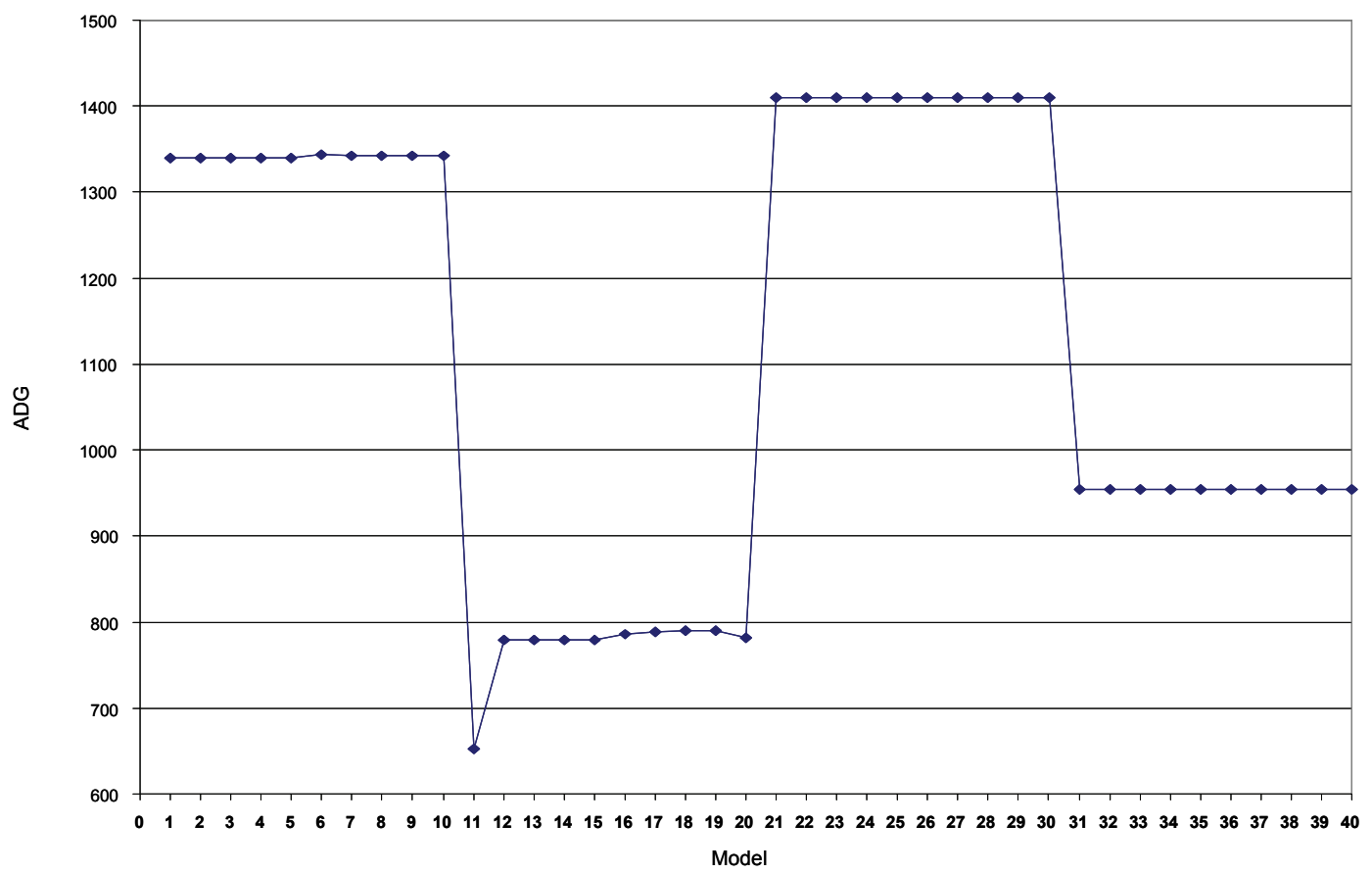

Fig. 3: Mean square errors of the applied models for average daily gain

(Mittlere quadratische Abweichung der angewandten Modelle für tägliche Zunahme) 


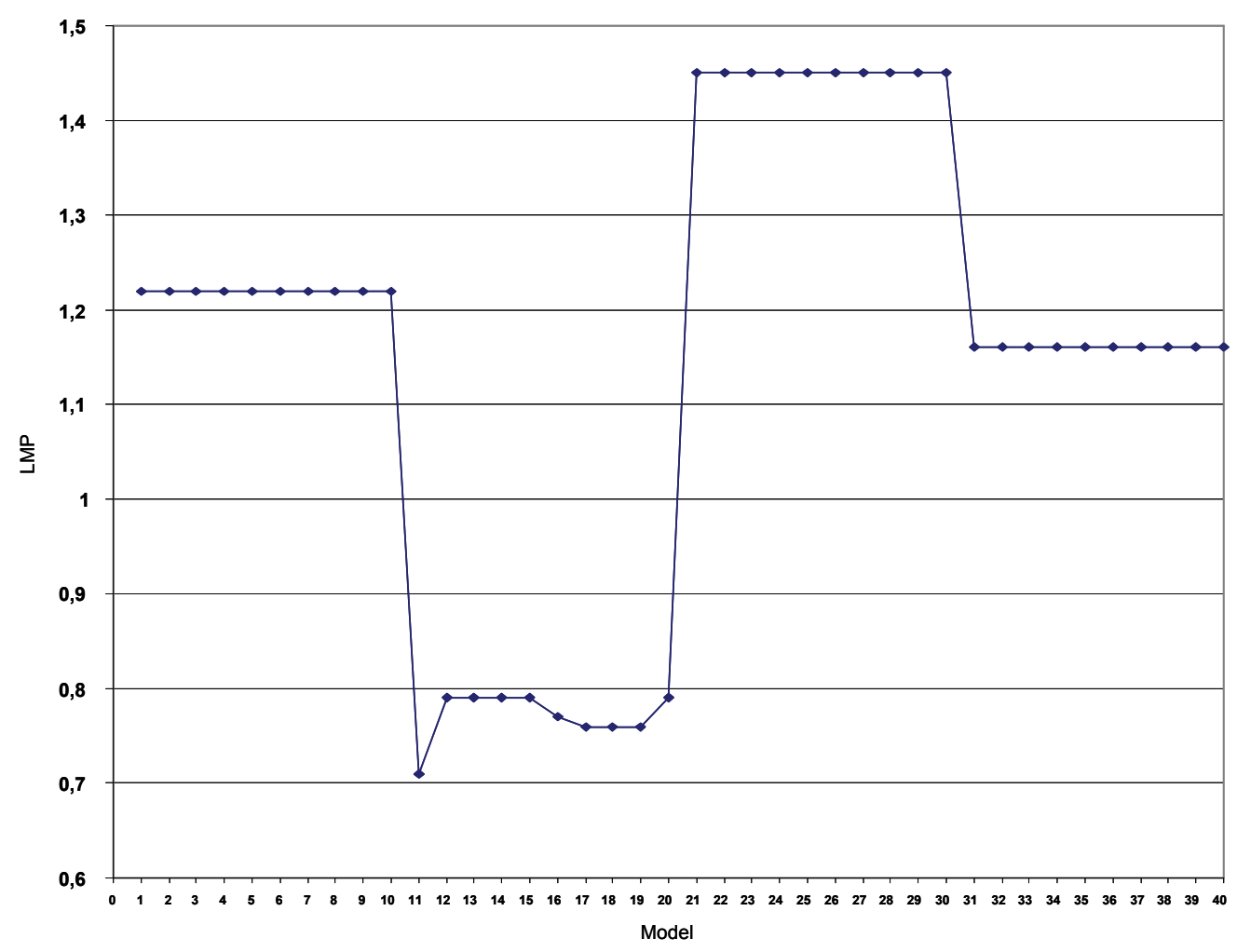

Fig. 4: Mean square errors of the applied models for lean meat percentage

(Mittlere quadratische Abweichung der angewandten Modelle für Muskelfleischanteil)

Models which contained litter effects (models 11-20, and 31-40) showed better fit compared to other models (models 1-10 and 21-30). This phenomenon was possibly caused by the additional relationship information that could be detected in the pedigree. Among the models contained litter effects the ones which containing yearmonth effect (models 11-20) showed better fit than the ones where the month effect was separated, while the effect of herd and the year effects were defined separately (models 31-40). Involving the continuous generations the accuracy of the estimation did not improved probably because of the very short pedigrees.

It can be concluded that due to the low inbreeding level and due to the small inbreeding depression of ADG and LMP, substantial depression can not be expected in the Hungarian Landrace in either trait in the near future. Nevertheless because field test data was available for a 12 years period, the estimated pedigree completeness was very low compared to the possible value (3-4) supposing more complete pedigrees. The absolute level of inbreeding of any animal depends on its pedigree length. Animals with long pedigree have higher probability of being inbred. Thus the negligible inbreeding depression was presumably partly the result of the short pedigrees. This suggests that conventional within group selection in the Hungarian Landrace nucleus farms has only secondarily importance. It is probable that pig breeders often import breeding animals or time to time accomplish total herd replacements.

\section{Acknowledgements}

Financial support of NKFP-4/ 057/2004 is gratefully acknowledged. 


\section{References}

BERESKIN, B.; SHELBY, C.E.; ROWE, K.E.; URBAN, W.E. JR.; BLUNN, C.T.; CHAPMAN, A.B.; GARWOOD, V.A.; HAZEL, L.N.; LASLEY, J.F.; MAGEE, W.T.; MCCARTY, J.W.; WHATLEY, J.A. JR.: Inbreeding and swine productivity traits. J. Anim. Sci. 27 (1968), 339-350

BOICHARD, D.:

Pedig: a Fortran package for pedigree analysis suited for large populations. $7^{\text {th }}$ WCGALP, Montpellier, France. August 19-23. (2002) Session 28, Communication No. 28-13

BOICHARD, D.; MAIGNEL, L.; VERRIER, É. The value of using probabilities of gene origin to measure genetic variability in a population. Genet. Sel. Evol. 29 (1997), 5-23

BRADE, W.:

Bewertung von Probanden anhand ingezüchteter Nachkommen - ein Überblick. Arch. Tierz. 34 (1991), 379-389

BRANDT, H.; MÖLLERS, B.:

Inzuchtdepression bei Merkmalen der Fruchtbarkeit und der Gewichtsentwicklung beim Göttinger Miniaturschwein. Arch. Tierz. 42 (1999), 601-610

CURIK, I.; SÖLKNER, J.; STIPIC, N.:

The influence of selection and epistasis on inbreeding depression estimates. J. Anim. Breed. Genet. 118 (2001), 247-262

DICKERSON, G.E.; BLUNN, C.T.; CHAPMAN, A.B.; KOTTMAN, R.M.; KRIDER, J.L.; WARWICK, E.J.; WHATLEY, J.A. JR.:

Evaluation of selection in developing inbred lines of swine. Research Bulletin. Missouri Agricultural Experiment Station No. 551 (1954)

FALCONER, D.S.; MACKAY, T.F.C.: Introduction to quantitative genetics. $4^{\text {th }}$ Ed. Longman, Harlow (1996)

FREYER, G.; HERNANDEZ-SANCHEZ, J.; CASSEL, B.C.:

A note on inbreeding in dairy cattle breeding. Arch. Tierz. 48 (2005), 130-137

GROENEVELD, E.:

PEST Users' Manual. Institute of Animal Husbandry and Animal Behaviour Federal Research Centre, Neustadt (1990)

HEDRICK, P.W.; KALINOWSKI, S.T.

Inbreeding depression in in conservation biology. Annu. Rev. Ecol. Syst. 31 (2000), 139-162

HORN, P.; MELEG, I.:

Inbreeding effects on production traits in pigeons. Arch. Geflügelk. 64 (2000), 273-277

ISSA, B.S.; SEELAND, G.:

Einfluss von Inzucht und Selektion auf die Fruchtbarkeit und das Wachstum der Maus. Arch. Tierz. 44 (2001), 671-676

KALLWEIT, E; BAULAIN, U.:

Reproduction performance and degree of inbreeding in a small Finnscheep population during a 34-year period. Arch. Tierz. 44 (2001) Special Issue, 263-270

KOLK GEN SUNDAG, C.K.; WREDE, J.; DISTL, O.:

Analyse der Populationsstruktur des Bunten Bentheimer Schweines. Arch. Tierz. 49 (2006), 447-461

KOVAC, M.; GROENEVELD, E.:

VCE-5 Users' Guide and Reference Manual Version 5.1. University of Ljubljana, Biotechnical Faculty, Department of Animal Science, Domzale, Slovenia. Institute of Animal Science Federal Agricultural Research Centre, Neustadt (2003)

MIGLIOR, F.; BURNSIDE, E.B.; KENNEDY, B.W.:

Production traits of Holstein cattle: estimation of nonadditive genetic variance and inbreeding depression. J. Dairy Sci. 78 (1995), 1174-1180

OMMI (National Institute for Agricultural Quality Control). Pig performance Testing Code. $5^{\text {th }}$ edition, Budapest (2004)

PIRCHNER, F.:

Schätzung inzuchtwirksamer effektiver Populationsgrössen aus Genfrequenzschwankungen bei Bayerischem Fleckvieh und Tiroler Grauvieh. Arch. Tierz. 45 (2002), 331-339

PIRCHNER, F.

Use of inbred sires to exploit epistatic variance. Arch. Tierz. 47 (2004), 605-608

SAS Institute Inc. SAS/STAT ${ }^{\circledR} 9.1$ User's Guide. Cary, NC, USA (2004) 
TRIEBLER, G.; GREGOR, G.; GERASCH, G.:

Experimentelle Ergebnisse der Anwendung von Inzucht, Inzuchtlinienkreuzung und Topcross beim Schwein und ihre Bedeutung für die Hybridzüchtung. I. Mitt.: experimentelle Inzuchtergebnisse. Arch. Tierz. 23 (1980), 169-182

WIENER, G.; LEE, G.J.; WOOLLIAMS, J.A.:

Effects of rapid inbreeding and crossing of inbred lines on the body weight growth of sheep. Anim. Prod. 55 (1992), 89-99

WOCAC, R.M.:

Bedeutung der Inzucht bei Tauernschecken-Ziegen. Arch. Tierz. 49 (2003), 455-469

WRIGHT, S.:

Coefficients of inbreeding and relationship. Amer. Nat. 56 (1922), 330-338

ZELLER, K.; PIRCHNER, F.:

Verwendung von ingezüchteten Bullen in der Zuchtarbeit. Arch. Tierz. 36 (1993), 245-264

Received: 2007-04-12

Accepted: 2008-07-25

Authors:

ZSÓFIA VÍGH*

PETRA GYOVAI

Assoc. Prof. LÁSZLÓ CSATÓ

ISTVAN NAGY

Department of Pig and Small Animal Production

ÁRPÁD BOKOR

Department of Production and Breeding of Ruminants and Horse

Assist. Prof. JÁNOS FARKAS

Department of Informatics

University of Kaposvár

Guba S. u. 40

7400 Kaposvár

Hungary

LÁSZLÓ RADNÓCZI

National Institute for Agricultural Quality Kontrol

Keleti Károly u 24

1024 Budapest

Hungary

Assoc. Prof. ISTVÁN KOMLÓSI

Centre of Agricultural Sciences

Department of Animal Science

University of Debrecen

Böszörményi ut 138

4032 Debrecen

Hungary

*Corresponding author

email: vzsofia@ke.hu 